\title{
IMPLEMENTASI METODE FUZZY TIME SERIES DENGAN MODEL ALGORITMA CHEN UNTUK MEMPREDIKSI HARGA EMAS
}

\author{
Darsono Nababan ${ }^{1}$, Eric Alexander ${ }^{2}$ \\ ${ }^{1}$ Program Studi Teknologi Informasi, Fakultas Sains dan Teknologi \\ Universitas Timor \\ Jl. Km. 09 Kefamenanu, Nusa Tenggara Timur \\ ${ }^{2}$ Program Studi Sistem Informasi, Fakultas Ilmu Komputer \\ Universitas Pelita Harapan \\ Jl. Iman Bonjol No.6 Lt.5-7 Lippo Plaza Medan, Sumatera Utara \\ 1'darsono.nababan@unimor.ac.id, ${ }^{2}$ alexander.ericd3@gmail.com
}

\begin{abstract}
Gold is one of the people's preferred forms of investment and is considered the safest (save-heaven). Gold risk which is considered small is the main attraction because in general Indonesian people are not yet familiar with capital market investments such as stocks and mutual funds. But the price of gold is very volatile as for the factors that affect the fluctuations of gold are consumption demand, volatility and market uncertainty, protection of low-interest rates, and the US dollar. Predicting the movement of the gold price and knowing where the direction of the exchange rate moves and determining the price of gold up or down cannot be done accurately and consistently. For this reason, in reducing the risk of loss, an application is needed to predict gold prices using the Fuzzy Time Series Chen algorithm using MATLAB software. In this study to obtain prediction results and comparison charts using actual data and prediction data for the 2015-2017 gold price. From the calculation results obtained by the prediction results with the Fuzzy Time Series method with the Chen algorithm where the average difference between the actual data and prediction data is not more than Rp. 2,850, - where predictions using the Fuzzy Time Series method Chen's algorithm is sufficient to use one data to predict the second data which makes this method accurate in predicting the price of gold.
\end{abstract}

Keywords: Gold, Investation, Fuzzy Time Series, Chen Algorithm, Prediction

\begin{abstract}
ABSTRAK
Emas merupakan salah satu bentuk investasi pilihan masyarakat dan dianggap paling aman (saveheaven). Risiko emas yang dianggap kecil menjadi daya tarik utama karena secara umum masyarakat Indonesia belum familiar dengan investasi pasar modal seperti saham dan reksadana. Tetapi harga emas sangat fluktuatif. Adapun faktor-faktor yang memepengaruhi fluktuasi daripada emas adalah permintaan konsumsi, votalitas dan ketidakpastian pasar, perlindungan terhadap suku bunga rendah dan dolar Amerika. Memprediksi pergerakkan harga emas dan mengetahui kemana arah nilai tukar bergerak serta menentukan harga emas naik atau turun tidak bisa dilakukan secara akurat dan konsisten. Untuk itu dalam mengurangi risiko kerugian maka diperlukan sebuah aplikasi untuk melakukan prediksi harga emas dengan menggunakan metode Fuzzy Time Series algoritma Chen dengan memanfaatkan software MATLAB. Dalam penelitian ini untuk mendapatkan hasil prediksi dan grafik perbandingan menggunakan data aktual dan data prediksi harga emas periode 2015 -2017. Dari hasil perhitungan diperoleh hasil prediksi dengan metode Fuzzy Time Series dengan algoritma Chen dimana selisih ratarata data aktual dengan data prediksi tidak lebih dari Rp. 2.850,- dimana prediksi menggunakan metode Fuzzy Time Series algoritma Chen cukup menggunakan satu data untuk memprediksi data ke-2 yang membuat metode ini dapat dikatakan akurat dalam memprediksi harga emas.
\end{abstract}

Kata Kunci: Emas, Investasi, Fuzzy Time Series, Algoritma Chen, Prediksi 


\section{PENDAHULUAN}

Investasi emas merupakan salah satu yang paling banyak di pilih oleh masyarakat menurut survei majalah SWA edisi Oktober 2013, emas merupakan pilihan investasi utama. Sekitar $50 \%$ kelas menengah yang di survei menempatkan investasinya dalam bentuk emas. Jauh meninggalkan instrumen investasi lainnya. Pandangan umum masyarakat mengenai emas dipandang memiliki risiko lebih rendah dibandingkan investasi lainnya seperti saham dan reksadana sehingga menjadi pilihan utama.

Harga emas selalu mengalami fluktuasi trend harga emas ditentukan setiap akhir hari, yang kemudian dirata-ratakan untuk mendapatkan harga tahunan.

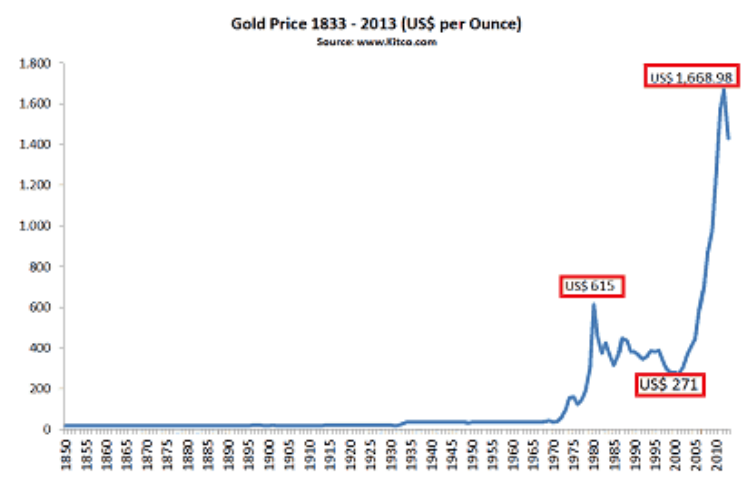

Gambar 1. Grafik harga emas tahun 1883 2013

Dalam grafik di atas sebelum 1970, harga emas cenderung stabil dan tidak mengalami fluktuasi tetapi setelah 1970 harga emas naik dengan tajam sampai sekarang. Dalam menetukan harga emas harus berpatokan kepada harga emas dunia, saat ini harga emas mencapai puncaknya memasuki era 2020 tetapi harga emas menunjukkan pola mean version dimana statistik menunjukkan harga emas akan cenderung kembali ke nilai rata-rata, harga akan berbalik arah, menurun atau meningkat.

Untuk meminimalisir kerugian yang diperoleh oleh masyarakat ataupun investor maka dapat menggunakan sistem untuk memprediksi harga emas dengan menggunakan metode fuzzy time series dengan algoritma Chen sebagai acuan untuk mengambil langkah yang tepat dalam berinvestasi. Dalam penelitian yang dilakukan oleh Riski Hamonangan dkk, tentang prediksi harga emas menggunakan metode genetic fuzzy dan arima bahwa fuzzy dengan yang telah dioptimasi dapat digunakan dalam memprediksi harga emas dengan metode yang terbaik dibandingkan dengan ARIMA [1]. Selain metode yang telah diuji dalam penelitian tersebut salah satu metode untuk memprediksi harga kenaikan atau penurunan harga emas adalah fuzzy time series dengan fuzzy set sebagai konsep dasar perhitungannya.

Penelitian yang serupa juga dilakukan oleh Lestari Handayani, dkk. untuk melakukan perbandingan model Chen dengan model Lee pada metode fuzzy time series untuk prediksi harga emas dari hasil pengujian yang dilakukan dengan menggunakan data dari tahun Januari 2007 hingga 29 mei 2012, diketahui bahwa prediksi data menggunakan fuzzy time series dengan penetuan interval berbasis rata-rata memiliki error dengan model Chen AFER sebesar 0,010\% dan MSE 218,577, model Lee rata-rata AFER 0,0013\% dan MSE 212,092. Dari hasil pengujian yang telah dilakukan dapat dibuktikan metode fuzzy time series menggunakan model Lee menghasilkan tingkat error lebih rendah dibanding model Chen [2].

Time series (deret waktu) adalah data yang disusun berdasarkan urutan waktu atau data yang dikumpulkan dari waktu ke waktu. Waktu yang digunakan dapat berupa hari, minggu, bulan, tahun dan sebagainya. Data time series sangat berguna bagi pengambil keputusan untuk memperkirakan atau meramalkan kejadian di masa yang akan datang. Karena diyakini pola perubahan data time series beberapa periode masa lampau akan kembali terulang pada masa kini. Metode fuzzy time series menggunakan model Song dan Chissom diimplementasikan untuk memprediksi jumlah pendaftaran kemudian model Song dan Chissom ini digunakan untuk memprediksi cuaca kurangnya tingkat keakuratan dengan menggunakan model tersebut kemudian disempunakan oleh Chen dan kemudian pada tahun 2009 ditemukanlah model Lee yang dianggap lebih baik dalam hal memprediksi dengan metode fuzzy time series dibanding model Chen dalam hal keakuratan atau evaluation MSE paling kecil [3].

Berdasarkan penelitian di atas, penulis melakukan prediksi terhadap harga emas menggunakan metode fuzzy time series model algoritma Chen dengan menggunakan interval dari tahun 2015 - 2017. Dengan interval waktu yang lebih lama akan mendapatkan hasil yang lebih akurat karena fuzzy time series bergantung pada interval waktu dalam hasil prediksi, sehingga pembentukan fuzzy relationship akan tepat. Metode untuk menentukan panjang 
interval yang akurat untuk hasil prediksi adalah dengan metode berbasis rata-rata atau averagebased fuzzy time series [2].

\section{METODOLOGI}

Berikut ini adalah langkah-langkah dalam memprediksi harga emas dengan menggunakan fuzzy time series dengan algoritma Chen.

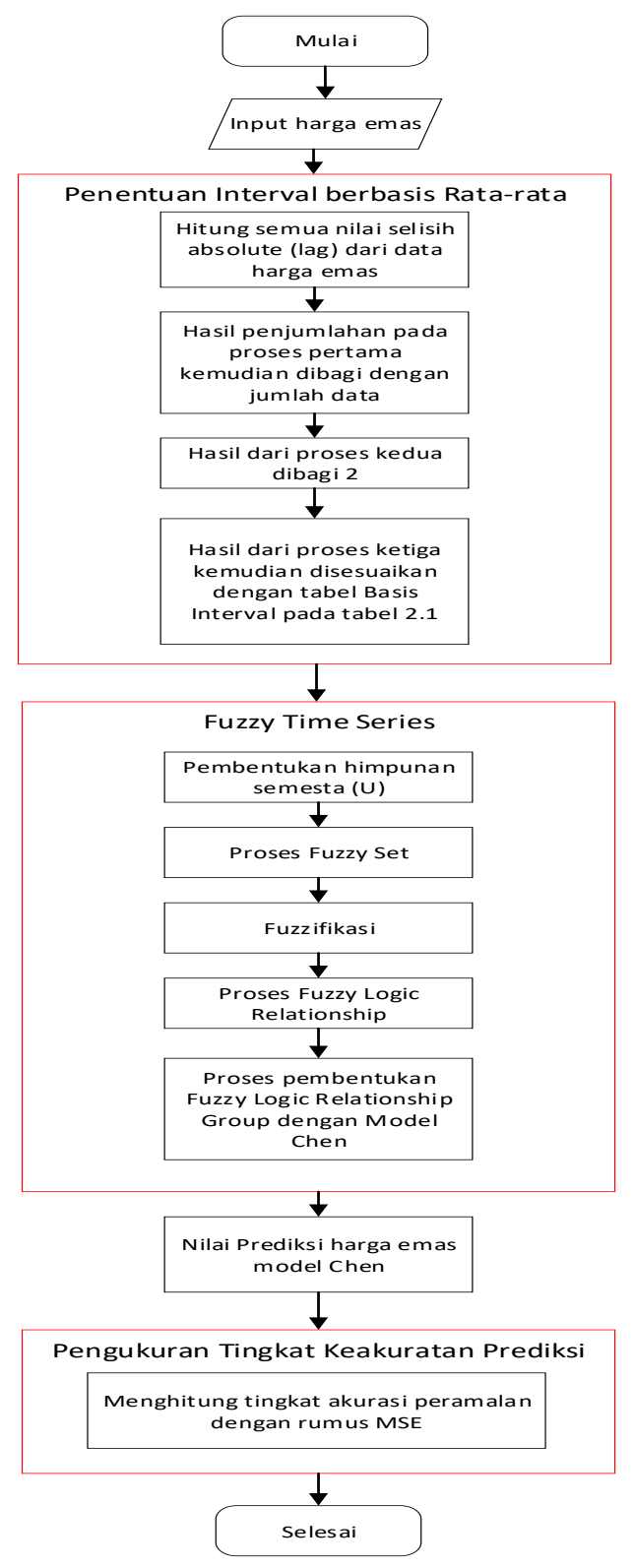

Gambar 2. Proses prediksi menggunakan metode fuzzy time series dengan penentuan interval berbasis rata-rata

\subsection{Proses Penentuan Interval Berbasis Rata-Rata \\ Dalam penerapan penentuan interval} berbasis rata-rata terdapat 4 (empat) tahapan dalam proses tersebut [3].

1. Menghitung semua nilai selisih (lag) absolute.

2. Hitung semua nilai selisih (lag) absolute kemudian dibagi dengan jumlah data.

3. Untuk penentuan basis interval, proses kedua dibagi 2 (dua).

4. Hasil dari proses ketiga sesuaikan dengan tabel basis interval untuk mendapatkan nilai interval berbasis rata-rata.

\subsection{Fuzzy Time Series}

Tahapan proses fuzzy time series adalah sebagai berikut [4]:

1. Pembentukan himpunan semesta $(U)$.

2. Tentukan setiap himpunan fuzzy $A i$ sebanyak interval yang telah dibagi pada tahap sebelumnya.

3. Melakukan proses fuzzifikasi, mengubah variabel non fuzzy (variabel numerik) menjadi variabel fuzzy (variabel linguistik).

4. Menentukan fuzzy logical relationship Ai $\rightarrow A j$ berdasarkan nilai $A i$ yang telah ditentukan pada tahap sebelumnya.

5. Dari hasil fuzzy logic relationship masuk dalam proses defuzzifikasi atau fuzzy logical relationship group menggunakan model Chen.

\subsection{Nilai Prediksi Harga Emas Model Chen}

Pengujian sistem pada aspek keakuratan nilai prediksi yaitu dilakukan dengan menguji dan membandingkan hasil nilai prediksi dengan nilai kebenaran harga emas yang sebenarnya [5].

\subsection{Pengukuran Nilai Hasil Prediksi Dengan Menggunakan MSE}

Dalam peramalan pasti terdapat kesalahan atau error karena tidak ada peramalan yang pasti akurat meskipun menggunakan berbagai metode peramalan. Dalam menggunakan berbagai macam metode peramalan maka harus memilih metode yang paling mendekati akurat, hal ini bisa dilihat dengan menggunakan pengukuran kesalahan atau penghitungan error [6]. Menghitung tingkat keakuratan prediksi menggunakan Mean Square Error [7].

$$
\mathrm{MSE}=\frac{\sum_{\mathrm{t}-1}^{\mathrm{n}}\left(\mathrm{Y}_{\mathrm{t}}-\widehat{\mathrm{Y}}_{(\mathrm{t})}\right)^{2}}{\mathrm{n}}
$$


Dengan:

$\mathrm{Y}_{\mathrm{t}}=$ Data aktual periode ke-t

$\widehat{Y}_{(t)}=$ Nilai peramalan periode ke-t

$\mathrm{n}=$ Banyaknya data yang diprediksi.

\subsection{Jenis dan Sumber Data}

Pada penelitian ini, penulis menggunakan data sekunder yang diperoleh dari www.hargaemas.org. Data harga emas dengan nilai kurs Rupiah ini terdiri dari periode 1 Januari 2015 hingga 31 Desember 2017. Data yang diambil berupa data harian yaitu Senin, Selasa, Rabu, Kamis, Jumat, Sabtu dan Minggu sebanyak kurang lebih 1.096 data [5]. Berikut ini merupakan history spot harga emas dunia per 31 Desember 2017.

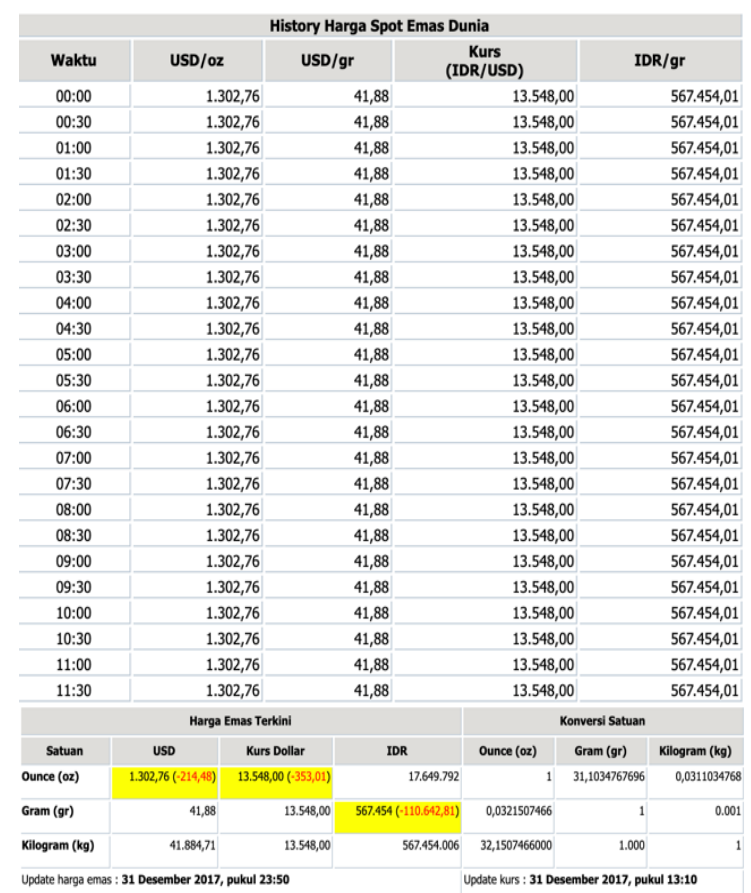

Gambar 3. History spot harga emas dunia (Sumber: www.harga-emas.org)

\section{HASIL DAN PEMBAHASAN}

Data master terdiri dari data harga emas harian sebanyak 1.096 hari dengan periode 1 Januari sampai dengan 31 Desember 2017 sebagai input data untuk menghasilkan output prediksi.
Tabel 1. Data harga emas periode Januari 2015 Desember 2017 (sumber: www.harga-emas.org).

\begin{tabular}{|c|c|c|c|c|c|}
\hline Jan & & & $\mathrm{Feb}$ & & \\
\hline Hari & $\mathrm{Tgl}$ & $\begin{array}{l}\text { Harga } \\
\text { Emas/gr }\end{array}$ & Hari & $\mathrm{Tgl}$ & $\begin{array}{l}\text { Harga } \\
\text { Emas / gr }\end{array}$ \\
\hline Kamis & $\begin{array}{l}01 \\
\text { Jan } \\
2015\end{array}$ & $\begin{array}{l}\mathrm{Rp} \\
473.307\end{array}$ & Minggu & $\begin{array}{l}01 \\
\text { Feb } \\
2015\end{array}$ & $\begin{array}{l}\mathrm{Rp} \\
521.058\end{array}$ \\
\hline Jumat & $\begin{array}{l}02 \\
\text { Jan } \\
2015\end{array}$ & $\begin{array}{l}\mathrm{Rp} \\
477.689\end{array}$ & Senin & $\begin{array}{l}02 \\
\text { Feb } \\
2015\end{array}$ & $\begin{array}{l}\mathrm{Rp} \\
520.070\end{array}$ \\
\hline Sabtu & $\begin{array}{l}03 \\
\text { Jan } \\
2015\end{array}$ & $\begin{array}{l}\mathrm{Rp} \\
477.007\end{array}$ & Selasa & $\begin{array}{l}03 \\
\text { Feb } \\
2015\end{array}$ & $\begin{array}{l}\mathrm{Rp} \\
512.086\end{array}$ \\
\hline$\ldots$ & $\ldots$ & $\ldots$ & $\ldots$ & $\ldots$ & $\ldots$ \\
\hline Nov & \multirow{2}{*}{$\mathrm{Tgl}$} & \multirow{2}{*}{$\begin{array}{l}\text { Harga } \\
\text { Emas / } \\
\text { gr }\end{array}$} & Des & \multirow{2}{*}{ Tgl } & \multirow{2}{*}{$\begin{array}{l}\text { Harga } \\
\text { Emas / } \\
\text { gr }\end{array}$} \\
\hline Hari & & & Hari & & \\
\hline Selasa & $\begin{array}{l}28 \\
\text { Nov } \\
2017\end{array}$ & $\begin{array}{l}\mathrm{Rp} \\
563.700\end{array}$ & Jumat & $\begin{array}{l}29 \\
\text { Des } \\
2017\end{array}$ & $\begin{array}{l}\mathrm{Rp} \\
567.724\end{array}$ \\
\hline Rabu & $\begin{array}{l}29 \\
\text { Nov } \\
2017\end{array}$ & $\begin{array}{l}\mathrm{Rp} \\
558.581\end{array}$ & Sabtu & $\begin{array}{l}30 \\
\text { Des } \\
2017\end{array}$ & $\begin{array}{l}\mathrm{Rp} \\
567.454\end{array}$ \\
\hline Kamis & $\begin{array}{l}30 \\
\text { Nov } \\
2017\end{array}$ & $\begin{array}{l}\mathrm{Rp} \\
554.833\end{array}$ & Minggu & $\begin{array}{l}31 \\
\text { Des } \\
2017\end{array}$ & $\begin{array}{l}\mathrm{Rp} \\
567.454\end{array}$ \\
\hline
\end{tabular}

\subsection{Penentuan Interval Berbasis Rata- Rata}

Perhitungan selisih absolute untuk mendapat rentang nilai pada nilai fuzzifikasi.

$$
\begin{aligned}
S_{n} & =\left|\mathrm{D}_{\mathrm{i}}-\mathrm{D}_{\mathrm{i}+1}\right| \\
S_{1} & =|473.307-477.689| \\
& =4.382
\end{aligned}
$$

\begin{tabular}{|c|c|}
\hline Nilai $S_{n}$ & Selisih Absolute \\
\hline$S_{1}$ & 4382 \\
\hline $\mathrm{S}_{2}$ & 682 \\
\hline $\mathrm{S}_{3}$ & 0 \\
\hline$S_{1093}$ & 3386 \\
\hline $\mathrm{S}_{1094}$ & 270 \\
\hline$S_{1095}$ & 0 \\
\hline
\end{tabular}

Proses perhitungan selisih absolute diteruskan hingga S1095, setelah perhitungan selesai.

Setelah selesai melakukan perhitungan selisih absolute, maka jumlah total dari selisih absolute adalah 2.914.005.

\subsection{Rata-rata Jumlah Selisih absolute}

Nilai rata-rata diperoleh dari jumlah selisih absolute dibagi dengan banyak data yaitu 1.096 data.

Rata-rata selisih $=\frac{\text { Jumlah selisih absolute }}{\text { Banyak data }}$ 


$$
\begin{aligned}
& =\frac{2.914 .005}{1.096} \\
= & 2.658,76
\end{aligned}
$$

\subsection{Rata-rata Selisih Dibagi Dua}

Hasil dari nilai rata-rata selisih kemudian dibagi 2 untuk menentukan basis interval.

$$
\begin{aligned}
\text { Nilai Basis } & =\frac{\text { Rata-rata selisih absolute }}{2} \\
& =\frac{2.658,76}{2} \\
& =1.329,38
\end{aligned}
$$

Nilai 1.329,38 kemudian dibulatkan sesuai dengan tabel basis interval yaitu 1000. Jumlah interval didapatkan dari hasil perhitungan.

$$
\begin{aligned}
\text { Interval } & =\frac{\text { Nilai Maksimum }- \text { Nilai Minimum }}{\text { Nilai Basis }} \\
& =\frac{578.444-466.801}{1000} \\
& =111.64 \\
& =112
\end{aligned}
$$

Setelah jumlah interval didapatkan, maka selanjutnya perhitungan untuk mendapatkan lebar interval pada himpunan semesta (U).

$$
\begin{aligned}
& \text { Interval }= \frac{\text { Nilai Maximum-Nilai Minimum }}{\text { Jumlah Interval }} \\
&=\frac{578.444-466.801}{112} \\
&=996,8125 \\
&=997
\end{aligned}
$$

Lebar interval himpunan fuzzy adalah:

$$
\begin{aligned}
& =\frac{\text { Nilai Maximum-Nilai Minimum }}{\text { Jumlah Interval-1 }} \\
& =\frac{578.444-466.801}{111} \\
& =1.005,79 \\
& =1006
\end{aligned}
$$

\subsection{Proses Fuzzy Time Series Model Algoritma Chen}

1. Pembentukan Himpunan Semesta (U)

Menentukan himpunan semesta dari Tabel 3 dengan mengambil harga emas terkecil hingga terbesar, didapatkan nilai terkecil adalah 466.801 dan nilai terbesar adalah 578.444, sehingga nilai $U$ adalah [466.801, 578.444].
Tahap ini adalah proses mentranformasi data pengamatan ke dalam bentuk himpunan fuzzy. Perhitungan himpunan semesta $U$ adalah sebagai berikut:

$$
\begin{aligned}
\mathrm{U}_{1} & =[466.801,466.801+997] \\
& =[466.801,467.798]
\end{aligned}
$$

Data himpunan semesta U sebanyak 112.

\begin{tabular}{cc}
\multicolumn{2}{c}{ Tabel 3. Hasil nilai interval himpunan semesta $U}$. \\
\hline Nilai U & Interval Himpunan Semesta U \\
\hline $\mathrm{U}_{1}$ & {$[466.801,467.798]$} \\
$\mathrm{U}_{2}$ & {$[467.798,468.795]$} \\
$\mathrm{U}_{3}$ & {$[468.795,469.792]$} \\
$\ldots$ & $\ldots$ \\
$\mathrm{U}_{110}$ & {$[575.474,576.471]$} \\
$\mathrm{U}_{111}$ & {$[576.471,577.468]$} \\
$\mathrm{U}_{112}$ & {$[577.468,578.465]$} \\
\hline
\end{tabular}

2. Proses fuzzy set

Tahap selanjutnya adalah proses fuzzy set untuk mengantisipasi nilai-nilai yang bersifat tidak pasti. Proses perhitungan fuzzy set adalah sebagai berikut:

$$
\begin{aligned}
& A_{1}=466.801 \\
& A_{2}=466.801+1.006=467.807 \\
& A_{3}=467.807+1.006=468.813
\end{aligned}
$$

Proses perhitungan fuzzy set diteruskan hingga $\mathrm{A}_{112}$, setelah perhitungan selesai, tabel fuzzy set dapat dilihat pada Tabel 4.

Tabel 3. Perhitungan fuzzy set $A_{1}-A_{112}$.

\begin{tabular}{cc}
\hline Nilai $\mathrm{A}_{\mathrm{n}}$ & Nilai fuzzy set \\
\hline $\mathrm{A}_{1}$ & 466.801 \\
$\mathrm{~A}_{2}$ & 467.807 \\
$\mathrm{~A}_{3}$ & 468.813 \\
$\ldots$ & $\ldots$ \\
$\mathrm{A}_{110}$ & 576.432 \\
$\mathrm{~A}_{111}$ & 577.438 \\
$\mathrm{~A}_{112}$ & 578.444 \\
\hline
\end{tabular}

3. Fuzzifikasi

Pada tahap ini, data yang bersifat numerik (nonfuzzy) dikonversi menjadi variabel linguistik (fuzzy) yang hasilnya dapat dapat dilihat pada Tabel 5. 
Tabel 4. Fuzzifikasi data aktual periode Januari

\begin{tabular}{|c|c|c|}
\hline Tanggal & Data Aktual & Fuzzifikasi \\
\hline $\begin{array}{l}\text { 01 Januari } \\
2015\end{array}$ & 473.307 & A7 \\
\hline $\begin{array}{l}\text { 02 Januari } \\
2015\end{array}$ & 477.689 & A12 \\
\hline $\begin{array}{l}\text { 03 Januari } \\
2015\end{array}$ & 477.007 & A11 \\
\hline$\ldots$ & $\ldots$ & \\
\hline $\begin{array}{l}29 \text { Desember } \\
2017\end{array}$ & 567.724 & A101 \\
\hline $\begin{array}{c}30 \text { Desember } \\
2017\end{array}$ & 567.454 & A101 \\
\hline $\begin{array}{c}31 \text { Desember } \\
2017\end{array}$ & 567.454 & A101 \\
\hline
\end{tabular}

4. Proses fuzzy logic relationship

Proses FLR terbentuk jika terdapat relasi dengan waktu berdasarkan urutan time seriesnya yang hasilnya dapat dapat dilihat pada Tabel 6.

\begin{tabular}{|c|c|}
\hline Time Series & FLR \\
\hline $\begin{array}{c}\text { 01-Jan-2015 } \rightarrow \text { 02-Jan- } \\
2015\end{array}$ & $\mathrm{~A}_{7} \rightarrow \mathrm{A}_{12}$ \\
\hline $\begin{array}{c}\text { 02-Jan-2015 } \rightarrow \text { 03-Jan- } \\
2015\end{array}$ & $\mathrm{~A}_{12} \rightarrow \mathrm{A}_{11}$ \\
\hline $\begin{array}{c}\text { 03-Jan-2015 } \rightarrow \text { 04-Jan- } \\
2015\end{array}$ & $\mathrm{~A}_{11} \rightarrow \mathrm{A}_{11}$ \\
\hline $\begin{array}{c}\text { 28-Des-2017 } \rightarrow 29- \\
\text { Des-2017 }\end{array}$ & $\mathrm{A}_{98} \rightarrow \mathrm{A}_{101}$ \\
\hline $\begin{array}{l}\text { 29-Des-2017 } \rightarrow 30- \\
\text { Des-2017 }\end{array}$ & $\mathrm{A}_{101} \rightarrow \mathrm{A}_{101}$ \\
\hline $\begin{array}{c}\text { 30-Des-2017 } \rightarrow 31- \\
\text { Des-2017 }\end{array}$ & $\mathrm{A}_{101} \rightarrow \mathrm{A}_{101}$ \\
\hline
\end{tabular}

Proses Fuzzy Logic Relationship Group (FLRG) adalah mengklasifikasikan FLR yang sama dan berulang, kemudian digabungkan menjadi satu grup. Tabel 7 adalah hasil dari FLRG.

Tabel 6. Tabel Fuzzy Logic Relationship Group (FLRG).

\begin{tabular}{cc}
\hline Current State & Next State \\
\hline A1 & A2, A5 \\
A2 & A2, A8 \\
A3 & - \\
$\ldots$ & $\cdots$ \\
A110 & - \\
A111 & A109 \\
A112 & A106, A109, A112 \\
\hline
\end{tabular}

5. Proses defuzzifikasi

Setelah menentukan FLRG, selanjutnya melakukan proses defuzzifikasi. Untuk grup dengan current state A1 maka hasil defuzzifikasi peramalannya adalah:

$$
\begin{aligned}
\mathrm{A}_{1} & =\frac{\mathrm{A}_{2}+\mathrm{A}_{5}}{2} \\
& =\frac{467.807+470.824}{2} \\
& =469.315,5
\end{aligned}
$$

Perhitungan nilai $A_{i}$ diteruskan sampai $A_{112}$ yang hasilnya dapat dapat dilihat pada Tabel 8 .

Tabel 7.Hasil defuzzifikasi FLRG.

\begin{tabular}{cc}
\hline Current State & Forecasted \\
\hline $\mathrm{A}_{1}$ & $469.315,48$ \\
$\mathrm{~A}_{2}$ & $470.824,17$ \\
$\mathrm{~A}_{3}$ & 0,00 \\
$\ldots$ & $\ldots$ \\
$\mathrm{A}_{110}$ & 0,00 \\
$\mathrm{~A}_{111}$ & $575.426,62$ \\
$\mathrm{~A}_{112}$ & $575.426,62$ \\
\hline
\end{tabular}

6. Hasil prediksi

Setelah proses defuzzikasi selesai, selanjutnya menentukan nilai prediksi dengan menggunakan bantuan dari proses fuzzifikasi yang hasilnya dapat dapat dilihat pada Tabel 9.

Tabel 8. Hasil prediksi fuzzifikasi data periode Januari 2015 - Desember 2017.

\begin{tabular}{ccc}
\hline Tanggal & Data Aktual & Manual \\
\hline 01 Januari & 473.307 & 0 \\
2015 & & \\
02 Januari & 477.689 & $474.243,8667$ \\
2015 & & \\
03 Januari & 477.007 & $477.613,2725$ \\
2015 & & \\
$\ldots$ & $\ldots$ & $\ldots$ \\
29 Desember & 567.724 & $564.362,9009$ \\
2017 & & \\
30 Desember & 567.454 & $566.374,4865$ \\
2017 & & \\
31 Desember & 567.454 & $566.374,4865$ \\
2017 & & \\
\hline Prediksi harga emas ke 1.097 & $566.374,4865$ \\
\hline
\end{tabular}

Berikut ini adalah proses untuk melakukan training data yang ditunjukkan pada Gambar 4.

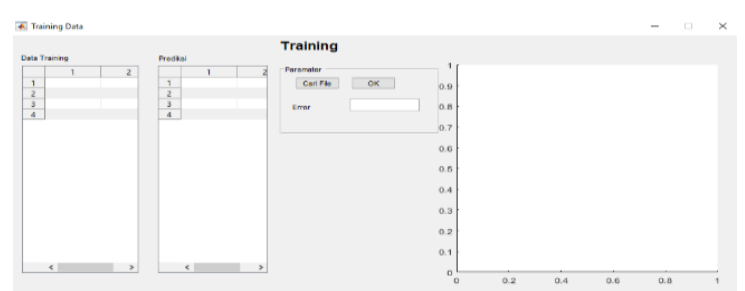

Gambar 4. Proses training data dengan tools MATLAB bebasis GUI 
Pada halaman ini terdapat 4 kolom, dimana kolom pertama adalah Training Data, user dapat memasukkan data historis harga emas dengan format file Excel .xlsx* atau .xls* dengan menekan button "Cari File" pada kolom ketiga. Pada kolom kedua berisi hasil prediksi setelah user menekan button "OK" pada kolom ketiga. Pada kolom ketiga terdapat Textfield nilai error yaitu perhitungan kesalahan pada proses prediksi harga emas. Pada kolom keempat akan ditampilkan grafik perbandingan hasil prediksi dengan harga aktual harga emas.

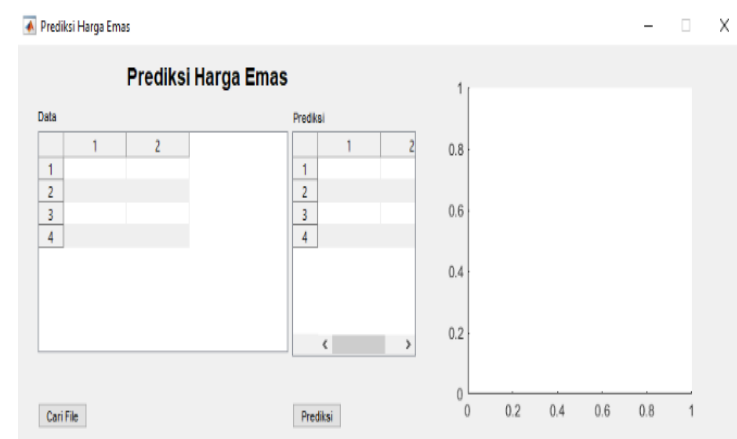

Gambar 1. Tampilan halaman prediksi harga emas

Pada halaman ini terdapat 3 kolom, kolom pertama adalah Data, user dapat memasukkan data historis harga emas dengan format file Excel .xlsx* atau .xls* dengan menekan button "Cari File" pada kolom pertama. Di kolom kedua berisi hasil prediksi setelah user menekan button "Prediksi" pada kolom kedua. Pada kolom ketiga akan ditampilkan grafik perbandingan hasil prediksi dengan harga aktual harga emas.

\section{Hasil perhitungan sistem}

Berikut ini adalah hasil prediksi dari sistem dengan menggunakan software MATLAB.

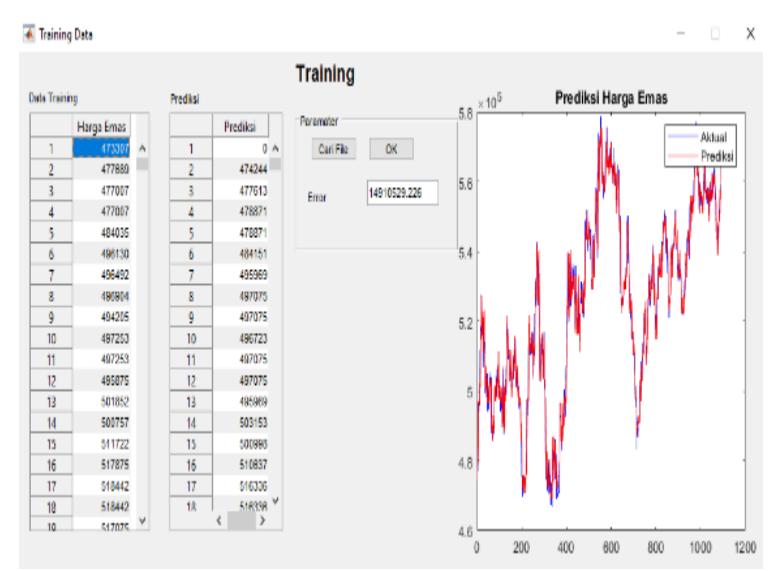

Gambar 2. Hasil prediksi training data

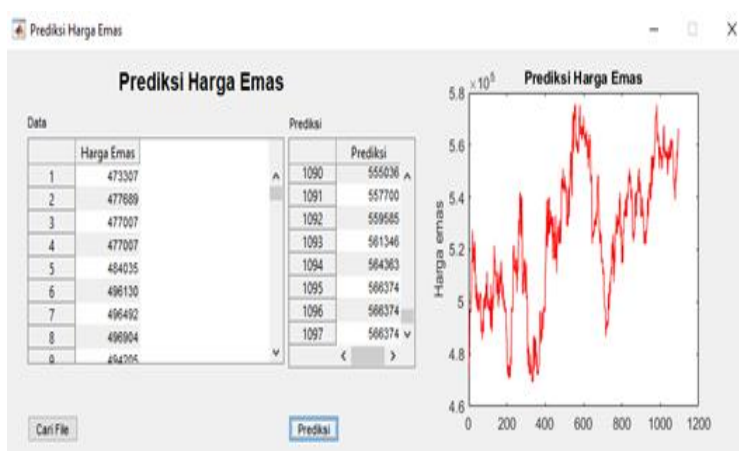

Gambar 3. Hasil prediksi harga emas

Hasil nilai prediksi dengan menggunakan sistem adalah:

Tabel 9. Hasil nilai prediksi data aktual dengan data perhitungan secara manual.

\begin{tabular}{ccc}
\hline Tanggal & Data Aktual & Manual \\
\hline 01 Januari & 473.307 & 0 \\
2015 & & \\
02 Januari & 477.689 & $474.243,8667$ \\
2015 & & \\
03 Januari & 477.007 & $477.613,2725$ \\
2015 & & \\
$\ldots$ & $\ldots$ & $\ldots$ \\
29 Desember & 567.724 & $564.362,9009$ \\
2017 & & \\
30 Desember & 567.454 & $566.374,4865$ \\
2017 & & \\
31 Desember & 567.454 & $566.374,4865$ \\
2017 & & \\
\hline Prediksi harga emas ke 1.097 & $566.374,4865$
\end{tabular}

8. Hasil analisis

Dari hasil perhitungan dengan data harga emas periode 1 Januari 2015 sampai 31 Desember 2017, diperoleh hasil prediksi dengan metode Fuzzy Time Series.

Tabel 10. Hasil perhitungan manual dan

\begin{tabular}{cccc}
\multicolumn{4}{c}{ perhitungan sistem. } \\
\hline Tangga & Data & Manual & Sistem \\
1 & Aktual & & \\
\hline 01 Jan & 473.30 & 0 & 0 \\
2015 & 7 & & \\
02 Jan & 477.68 & $474.243,866$ & $474.243,866$ \\
2015 & 9 & 7 & 7 \\
03 Jan & 477.00 & $477.613,272$ & $477.613,272$ \\
2015 & 7 & 5 & 5 \\
$\ldots$ & $\ldots$ & $\ldots$ & $\ldots$ \\
29 Des & 567.72 & $564.362,900$ & $564.362,900$ \\
2017 & 4 & 9 & 9 \\
30 Des & 567.45 & $566.374,486$ & $566.374,486$ \\
2017 & 4 & 5 & 5 \\
31 Des & 567.45 & $566.374,486$ & $566.374,486$ \\
2017 & 4 & 5 & 5 \\
\hline Prediksi harga & $566.374,486$ & $566.374,486$ \\
emas ke 1.097 & 5 & 5 \\
\hline
\end{tabular}


Dari tabel di atas dapat dilihat bahwa uji prediksi harga emas, hasil perhitungan secara manual sesuai dengan hasil perhitungan secara sistem dimana menghasilkan nilai output yang sama. Hal ini menunjukkan bahwa proses perhitungan rumus sudah sesuai dengan alur program prediksi harga emas.

$=\frac{\text { Total selisih nilai aktual dengan nilai prediksi }}{\text { Jumlah data }}$

$=\frac{3.120 .515,9365}{1095}$

$=2.849,7862$

$=2.850$

Selisih rata-rata data aktual dengan nilai prediksi tidak lebih dari Rp. 2.850, oleh karena itu sistem prediksi ini dapat menjadi acuan dalam memprediksi harga nilai emas dengan menggunakan metode Fuzzy Time Series algoritma Chen.

\section{PENUTUP}

Dari hasil pengujian dan analisis prediksi harga emas dengan menggunakan metode Fuzzy Time Series algoritma Chen, maka dapat diambil kesimpulan sebagai berikut bahwa data aktual harga emas tidak banyak berbeda dengan harga emas di data prediksi yaitu tidak mencapai $\mathrm{Rp} 2.850$, dapat dikatakan bahwa sistem yang menggunakan metode Fuzzy Time Series algoritma Chen akurat dalam memprediksi harga emas 1 hari ke depan dan dapat diajukan sebagai acuan untuk berinvestasi emas. Jumlah data aktual yang digunakan sebagai acuan perhitungan pola data serta jumlah interval pada saat perhitungan pola data sehingga memberikan pengaruh pada hasil peramalan. Jumlah interval yang digunakan dalam membagi data untuk perhitungan juga memberikan pengaruh pada hasil peramalan. Metode Fuzzy Time Series cocok digunakan dalam memprediksi pada data yang memiliki pola horizontal daripada data yang memiliki pola trend.

\section{DAFTAR PUSTAKA}

[1] A. R.Simanjuntak, "Prediksi Harga Emas Dengan Metode Genetic Fuzzy System Dan Arima," vol. 2, no. 1, pp. 1816-1821, 2015.

[2] Song, Qiang, and Brad S. Chissom. "Forecasting Enrollments with Fuzzy Time Series." (1991).

[3]. Qiu, Wangren, Xiaodong Liu, and Hailin Li. "A generalized method for forecasting based on fuzzy time series." Expert Systems with Applications 38.8 (2011): 10446-10453.

[4]. D Anggriani, Darni. Perbandingan Model Chen Dan Model Lee Pada Metode Fuzzy Time Series Untuk Prediksi Harga Emas. Diss. UNIVERSITAS ISLAM NEGERI SULTAN SYARIEF KASIM RIAU, 2012.

[5] www.harga-emas.com diakses pada tanggal 1 mei 2019.

[6] Saragih, Rijois Iboy Erwin, and Darsono Nababan. "Increase Performance Genetic Algorithm In Matching System By Setting GA Parameter." Journal of Physics: Conference Series. Vol. 1175. No. 1. IOP Publishing, 2019

[7] H. T. S. P. H. Ikhsanto, "Perbandingan Tingkat Akurasi Metode Automatic Clustering, Average Based, Dan Markov Chain Fuzzy Time Series Pada Nilai Tukar (Kurs) Rupiah,” Unnes J. Math. Educ., Vol. 4, No. 2, Pp. 66-82, 2015

\section{Hak Cipta}

Semua naskah yang tidak diterbitkan, dapat dikirimkan di tempat lain. Penulis bertanggung jawab atas ijin publikasi atau pengakuan gambar, tabel dan bilangan dalam naskah yang dikirimkannya. Naskah bukanlah naskah jiplakan dan tidak melanggar hak-hak lain dari pihak ketiga. Penulis setuju bahwa keputusan untuk menerbitkan atau tidak menerbitkan naskah dalam jurnal yang dikirimkan penulis, adalah sepenuhnya hak Pengelola. Sebelum penerimaan terakhir naskah, penulis diharuskan menegaskan secara tertulis, bahwa tulisan yang dikirimkan merupakan hak cipta penulis dan menugaskan hak cipta ini pada pengelola. 